\title{
СПОРТИВНАЯ КОРПОРАТИВНАЯ ДИСКВАЛИФИКАЦИЯ КАК СПЕЦИАЛЬНОЕ ОСНОВАНИЕ ПРЕКРАЩЕНИЯ ТРУДОВОГО ДОГОВОРА СО СПОРТСМЕНОМ
}

\author{
А. Х. Сафин \\ Национальный исследовательский университет \\ "Высшая школа экономики" \\ Поступила в редакцию 28 августа 2021 г.
}

\begin{abstract}
Аннотация: статья посвящена исследованию спортивной корпоративной дисквалифбккации как самостоятельного вида ответственности спортсмена. Обосновывается необходимость разграничения для иелей трудового законодательства РФ спортивной корпоративной дисквалифбикаиии и спортивной дисквалификаиии, приводятся позииии судебньх органов в отношении указанного вида ответственности. Предлагаются изленения в действующее трудовое законодательство, связаннье с введениел спортивной корпоративной дисквалификаиии как салостоятельного основания прекращения трудового договора со спортсленол.

Ключевые слова: спортивная корпоративная дисквалификаиия, труд спортсленов, прекращение трудового договора, спортивная дисквалификаиия.
\end{abstract}

\begin{abstract}
: the article is devoted to the study of sports corporate disqualification as an independent type of responsibility of an athlete. The article substantiates the need to distinguish between sports corporate disqualification and sports disqualification for the purposes of the labor legislation of the Russian Federation, and provides the positions of the judicial authorities in relation to this type of liability. The amendments to the current labor legislation related to the introduction of sports corporate disqualification as an independent basis for termination of the employment contract with an athlete are also proposed.
\end{abstract}

Key words: sports corporate disqualification, work of athletes, termination of the employment contract, sports disqualification.

Трудовые правоотношения спортсменов имеют целый ряд особенностей, в связи с чем законодатель обоснованно применил метод диффреренциации правового регулирования данных правоотношений, дополнив Трудовой кодекс РФ специальной главой 54.1 «Особенности регулирования труда спортсменов и тренеров». В числе особенностей были определены и дополнительные основания прекращения трудового договора со спортсменами, в соответствии со ст. 348.11 Трудового кодекса РФ спортивная дисквалификация на срок шесть и более месяцев либо нарушение спортсменом, в том числе однократное, общероссийских антидопинговых правил и (или) антидопинговых правил, утвержденных международными

(C) Сафин А. X., 2021 


\section{Вестник ВГУ. Серия: Право}

антидопинговыми организациями, признанное нарушением по решению соответствующей антидопинговой организации ${ }^{1}$.

В то же время трудовые правоотношения спортсменов, помимо Трудового кодекса РФ, регулируются нормами, утвержденными общероссийскими спортивными фредерациями и профессиональными спортивными лигами. Указанные нормы являются составной частью положений (регламентов) спортивных соревнований, право на утверждение и изменение которых дано вышеуказанным субъектам Федеральным законом «О фризической культуре и спорте в Российской Федерации» (далее - Закон о спорте $)^{2}$. При этом регулирование общероссийских спортивных фредераций и профессиональных спортивных лиг нередко вступает в противоречие с нормами Трудового кодекса РФ. Даже с учетом таких противоречий, указанные нормы, утвержденные общероссийскими спортивными фредерациями и профессиональными спортивными лигами, активно применяются на практике. Одним из примеров таких норм является спортивная корпоративная дисквалификация, которая включает запрет на осуществление отдельных функций, любые дисквалификации, упоминаемые в регламентах общероссийских спортивных федераций и профессиональных спортивных лиг, за исключением спортивной дисквалификации. Она закреплена во многих регламентах общероссийских спортивных федераций и профрессиональных спортивных лиг. В частности, в ст. 12 Дисциплинарного регламента КХЛ ${ }^{3}$ установлено, что спортивной корпоративной дисквалификацией является:

для фризического лица - лишение права занимать любые должности и исполнять обязанности (в том числе спортсмена-инструктора, спортсмена-хоккеиста, тренера, врача, менеджера, директора и др.) в Клубах КХЛ, МХЛ, ЖХЛ и (или) лишение права быть назначенным лицом, выполняющим управленческие фрункции в структуре КХЛ, МХЛ, ЖХЛ и/или в структуре Клубов КХЛ, МХЛ и ЖХЛ на определенный срок или бессрочно;

для юридического лица - лишение права вступать в спортивные корпоративные отношения с другими юридическими лицами (в том числе с Клубами) в структуре КХЛ, МХЛ; быть участником чемпионата на определенный срок или бессрочно.

Согласно п. 2 ст. 12 Дисциплинарного регламента КХЛ спортивная корпоративная дисквалификация не обжалуется в судебном либо ином порядке, но может быть отменена при рассмотрении Дисциплинарным комитетом КХЛ заявления заинтересованного лица об отмене спортивной корпоративной дисквалификации с учетом всех обстоятельств дела (события), добровольного исполнения наказания, раскаяния нарушителя, а также

${ }^{1}$ Трудовой кодекс Российской Федерации : федер. закон от 30 декабря 2001 г. № 197-ФЗ // Собр. законодательства Рос. Федерации. 2001. № 1. Ст. 3.

${ }^{2} \mathrm{O}$ физической культуре и спорте в Российской Федерации : федер. закон от 4 декабря 2007 г. № 329-ФЗ // Собр. законодательства Рос. Федерации. 2007. № 50. Ст. 6242.

${ }^{3}$ Дисциплинарный регламент КХЛ : утвержден Советом директоров ООО «КХЛ» № 75 от 14 июля 2017 г. // Официальный сайт КХЛ. URL: https://www.khl. ru/documents/KHL_disciplinary_regulations_2020.pdf 
при условии истечения с момента наложения спортивной корпоративной дисквалификации не менее шести месяцев.

При этом согласно ст. 12 Дисциплинарного регламента КХЛ продолжение исполнения трудовых обязанностей дисквалифрицированным лицом не представляется возможным, поскольку на дисквалифицированное фризическое лицо может быть наложен штрафр в размере 100 тысяч рублей, на дисквалифицированное юридическое лицо - в размере 300 тысяч рублей.

Отдельно в ст. 12 Дисциплинарного регламента КХЛ установлена мера ответственности в отношении юридического лица, которое заключает с дисквалифицированным лицом трудовой договор либо не расторгает действующий трудовой договор с дисквалифицированным лицом. Штраф устанавливается на уровне 300 тысяч рублей.

В регламентах других видов спорта спортивная корпоративная дисквалификация прямо не поименована. В Дисциплинарном регламенте ФХР 4 проводится разграничение между спортивной дисквалификацией, предполагающей отстранение спортсмена или иного официального лица Клуба от участия в соревнованиях, и запретом на выполнение лицом конкретных функций, выражающимся в запрете лицу на определенное количество матчей либо пожизненно осуществлять функцию, непосредственно связанную с деятельностью в хоккее. В футболе разграничений между видами дисквалификации не проводится: в соответствии с Дисциплинарным регламентом Российского футбольного союза ${ }^{5}$ использован аналогичный ФХР подход. К спортсменам и официальным лицам Клуба применяется спортивная дисквалификация. Имеется также такая санкция, как запрет на осуществление любой связанной с футболом деятельности (ст. 18 Дисциплинарного регламента РФС), применяемой по отношению ко всем фиизическим лицам, в том числе спортсменам.

Спортивную корпоративную дисквалификацию нельзя понимать как составную часть спортивной дисквалифрикации, поскольку в силу ст. 1 Закона о спорте последняя предполагает отстранение спортсмена от участия в спортивных соревнованиях, которое осуществляется международной спортивной фредерацией по соответствующему виду спорта или общероссийской спортивной фредерацией по соответствующему виду спорта за нарушение правил вида спорта, или положений (регламентов) спортивных соревнований, или антидопинговых правил, или норм, утвержденных международными спортивными организациями, или норм, утвержденных общероссийскими спортивными фредерациями.

Законодательное определение «спортивной дисквалификации» предполагает ее применение исключительно к спортсменам, а не к иным официальным лицам Клуба. Спортивная дисквалификация не предполагает запрета заниматься любой деятельностью, связанной с данным видом

${ }^{4}$ Дисциплинарный регламент ФХР : утвержден решением Правления ФХР от 27 июня 2016 г. № 3/16 // Официальный сайт ФXP. URL: https://fhr.ru/upload/ iblock/25c/Distsiplinarnyy_reglament_FKHR

${ }^{5}$ Дисциплинарный регламент РФС : утвержден постановлением Исполкома Общероссийской общественной организации «Российский фрутбольный союз» от 23 декабря 2010 г. № 65/2 с последующими изменениями и дополнениями // Официальный сайт PФC. URL: https://static.rfs.ru/documents/1/5f439f85705f4.pdf 
спорта, а распространяется исключительно на соревновательную деятельность. Спортивная дисквалификация осуществляется либо международной спортивной федерацией либо общероссийской спортивной федерацией по соответствующему виду спорта. Профрессиональная спортивная лига в число субъектов, накладывающих спортивную дисквалификацию, не входит. Такой подход отчасти подтверждается ст. 14 Дисциплинарного регламента КХЛ, которая определяет спортивную дисквалификацию как запрет на участие в предстоящем матче (матчах) или в течение определенного периода в случаях и по основаниям, прямо предусмотренным законодательством Российской Федерации, т. е. в части применения дисквалификации делается отсылка как к законодательству Российской Федерации. Отличительной особенностью Регламента КХЛ является возможность применения спортивной корпоративной дисквалификации к юридическим лицам. Таким образом, понятие «спортивная корпоративная дисквалификация» является более широким, чем «спортивная дисквалификация».

При этом в действующем законодательстве такое самостоятельное основание прекращения трудового договора со спортсменом, как спортивная корпоративная дисквалификация, отсутствует. Следовательно, работодатель - профессиональный клуб - оказывается в ситуации, когда он либо вынужден увольнять работника неправомерно, либо уплачивать штрафы на регулярной основе за нарушение регламента соревнований.

Невключение спортивной корпоративной дисквалификации в Трудовой кодекс РФ создает негативные имущественные последствия для работодателя, что подтверждается судебной практикой. Пытаясь избежать конфликтной ситуации с организатором соревнований, профессиональные спортивные клубы пытались применять по аналогии п. 8 ст. 83 Трудового кодекса РФ, а именно в качестве основания прекращения трудового договора выступала дисквалификация или иное административное наказание, исключающее возможность исполнения работником обязанностей ๓ по трудовому договору. На уровне суда первой инстанции такой подход 이 был поддержан. Суд первой инстанции, руководствуясь положениями ФеZ дерального закона от 4 декабря 2007 г. № 329-ФЗ «О физической культуре テ и спорте в Российской Федерации», Правовым регламентом КХЛ, Дисци을 плинарным регламентом КХЛ, пришел к выводу, что поскольку работник отказался в добровольном порядке исполнить решение КХЛ, у ответчика имелись основания для увольнения истца по п. 8 ч. 1 ст. 83 ТК РФ в связи

146 с дисквалификацией, исключающей возможность исполнения работником обязанностей по трудовому договору.

Однако апелляционная инстанция не согласилась с вышеуказанным подходом. В частности, апелляционным определением Приморского краевого суда по делу № 33-9461 от 3 сентября 2019 г. ${ }^{6}$ работник, к которому была применена спортивная корпоративная дисквалификация и с которым Клуб прекратил трудовые отношения на основании п. 8 ст. 83 Трудового кодекса РФ, был восстановлен в должности, в пользу работника была взыскана заработная плата за время вынужденного прогула, а также компенсация морального вреда.

${ }^{6}$ Апелляционное определение Приморского краевого суда по делу № 33-9461 от 3 сентября 2019 г. URL: http://kraevoy.prm.sudrf.ru/ 
Свое решение суд обосновал тем, что основанием для увольнения работника по п. 8 ч. 1 ст. 83 ТК РФ является дисквалификация или иное административное наказание, исключающее возможность исполнения работником обязанностей по трудовому договору.

При этом дисквалификация должна быть санкцией, установленной административным наказанием или в связи с приговором суда.

Учитывая, что дисквалификация является видом административного наказания, лицо подлежит административной ответственности только за те административные правонарушения, в отношении которых установлена его вина.

Принимая во внимание, что постановление суда о применении к работнику такого вида административной ответственности, как дисквалифрикация, профессиональным клубом не было представлено, как и не был представлен приговор суда, предусматривающий наказание в виде дисквалификации, приказ об увольнении работника не мог быть признан законным и обоснованным, что послужило основанием для восстановления работника в должности.

При этом в отношении самой спортивной корпоративной дисквалификации суд указал, что подп. 1.1 п. 1 ст. 12 Дисциплинарного регламента КХЛ, предусматривающий спортивную санкцию в виде лишения права занимать любые должности в структуре Клубов КХЛ, ограничивает право гражданина Российской Федерации свободно распоряжаться своими способностями к труду, гарантированное ч. 1 ст. 37 Конституции РФ, а также нарушает один из основных принципов регулирования трудовых отношений, закрепленный в абзаце 2 ст. 2 Трудового кодекса РФ, а именно принцип свободы труда, включая право на труд, который каждый свободно выбирает или на который свободно соглашается, право распоряжаться своими способностями к труду, выбирать профессию и род деятельности, а также ограничивает право работника обращаться в органы рассмотрения индивидуальных трудовых споров, по данному вопросу.

Такой подход суда вызывает сомнения. Необходимо подчеркнуть, что право на труд, включающее занятие профессией и род деятельности, упоминается здесь в целом. В то же время при применении спортивной корпоративной дисквалификации ограничивается лишь трудоустройство в ООО «КХЛ» и клубах лиги. Говорить об ограничении права на труд уместно после получения конкретного отказа в приеме на работу в связи с вынесенным решением о спортивной корпоративной дисквалификации.

Решение о корпоративной дисквалификации, как и указано в названии вида наказания, имеет корпоративный характер, и вынесенное наказание имеет информационный характер для клубов КХЛ и непосредственно КХЛ, договорившихся о корпоративных принципах. Корпоративная дисквалификация не влечет незамедлительного прекращения трудовых отношений между работодателем и работником.

Полагаем, что спортивная корпоративная дисквалификация, активно применяемая на практике общероссийскими спортивными федерациями и профессиональными спортивными лигами, нуждается в закреплении на законодательном уровне. 
В связи с этим предлагается изменить ст. 83 Трудового кодекса РФ «Прекращение трудового договора по обстоятельствам, не зависящим от воли сторон» путем включения такого дополнительного основания прекращения трудовых отношений, как спортивная корпоративная дисквалификация. Включение указанного основания прекращения трудовых отношений в главу 54.1 Трудового кодекса, посвященную правовому регулированию труда спортсменов и тренеров, не устранит пробел в правовом регулировании полностью, поскольку санкция в виде спортивной корпоративной дисквалификации применяется не только к спортсменам и тренерам, но и иным субъектам спорта. При этом можно реализовать подход, при котором в главу 54.1 будут включены, помимо спортсменов и тренеров, иные работники в сфере спорта, включая руководителей клубов, генеральных менеджеров, спортивных директоров и иных работников профессиональных спортивных клубов и лиг. Вместе с тем такой подход потребует комплексной переработки главы 54.1 Трудового кодекса РФ, что может быть проблематично.

Таким образом, спортивная корпоративная дисквалификация требует законодательного закрепления, поскольку профессиональные спортивные лиги и общероссийские спортивные федерации заинтересованы в том, чтобы привлекать к ответственности злостных нарушителей их норм. При этом указанное соблюдение корпоративных принципов не должно создавать проблем для профессиональных клубов и иных работодателей, где трудоустроен спортсмен. Установление в качестве дополнительного основания прекращения трудового договора спортивной корпоративной дисквалификации позволит избежать вышеописанных сложностей.

\section{Для иитирования:}

Сафин А. X. Спортивная корпоративная дисквалификация как специальное основание прекращения трудового договора со спортсменом // Вестник Воронежского государственного университета. Серия: Право. 2021. № 3 (46). С. 143-148. DOI: https:// doi.org/10.17308/vsu.proc.law.2021.3/3592

\section{Recommended citation:}

Safin A. Kh. Sports corporate disqualification as a special ground for termination of an employment contract with an athlete // Proceedings of Voronezh State University. Series: Law. 2021. № 3 (46). P. 143-148. DOI: https://doi.org/10.17308/vsu.proc.law.2021.3/3592

Национальный исследовательский университет "Высшая школа эконоликu»

Сафбин A. X., аспирант

E-mail:a.safin@hse.ru
National Research University "Higher School of Economics"

Safin A. Kh., Post-graduate Student

E-mail:a.safin@hse.ru 